\title{
O LIVRO CASA OU MORADA, PERCEBIDO NA EXPERIÊNCIA E DECLARADO NA ESCRITA: UM MODO DE LER E SEUS DESDOBRAMENTOS
}

\section{THE BOOK CASA OU MORADA PERCEIVED IN EXPERIENCE AND DECLARED IN WRITING: A WAY TO READ AND ITS DEVELOPMENTS}

Fabiano Tadeu Grazioli

Universidade Regional Integrada do Alto Uruguai e das Missóes, URI, Erechim, RS, Brasil

\begin{abstract}
Resumo: $\mathrm{O}$ artigo procura refletir sobre o aproveitamento do livro em seu vínculo com a noção de casa, bem como seus sinônimos mais recorrentes, em escritos teóricos de Walter Benjamin (2002), Alberto Manguel (2010), e Michèle Petit (2009), enquanto um modo de perceber a experiência da leitura e de projetar um sentido para ela, atividades aqui consideradas modos de ler. No esforço de entender a utilização da expressão nas particularidades de cada autor, bem como a adesão à analogia - movimentos que exigiram expandir o olhar para além dos fragmentos nos quais as expressōes em questão estavam inseridas -, encaminham-se as reflexóes para diversas veredas e percebe-se facilmente a comunháo do sentido pelos autores.
\end{abstract}

Palavras-chave: casa; morada; livro; leitura.

Abstract: The article reflects on the usage of the book in its connection with the notion of home, as well as its most recurrent synonyms and it is based on theoretical writings of Walter Benjamin (2002), Alberto Manguel (2010), and Michèle Petit (2009). Furthermore, as a way of perceiving the reading experience and projecting a meaning for it, activities are considered ways of reading. To understand the use of the expression in the particularities of each author, as well as adherence to the analogy - movements that required expanding the look beyond the fragments in which the expressions in question were inserted - reflections are directed to different paths and it is easy to perceive the communion of meaning by the authors.

Keywords: house, habitation, book, reading.

\section{Os contornos mais ou menos sinuosos da planta}

Há de se reconhecer uma tentativa quase infantil, tomada aqui como acriançada, inocente e primária, inaugural e maculada, como vamos explicar 
nas próximas linhas na natureza da escrita acadêmica, como a tentativa de montagem de um quebra-cabeça. Você realizou determinadas leituras, elas parecem repousar no seu intelecto. Até que você lê a chamada para um dossiê específico e começa a brincadeira, o jogo ou a atividade lúdica. Vai à procura das peças, cada qual guardada em um lugar específico, desloca-as e traz para esse espaço lúdico que é o texto - e começa o encaixe! Entre as peças, vai sobrepondo aquelas que você já consegue oferecer ao jogo, as quais, bem da verdade, precisam se sobressair na brincadeira, apesar de reconhecer a necessidade das outras peças para que a atividade lúdica ocorra. E, assim, constrói a estrutura, um conjunto de peças, um quebra-cabeça quase pronto que permite visualizar uma imagem, com algum contorno e significado.

Do impulso lúdico, projeta-se e elabora-se uma contribuição acadêmica. Esse movimento lembra-nos de imediato o pensador holandês Johan Huizinga, que, em seu estudo Homo ludens: o jogo como elemento da cultura, publicado originalmente em 1938, que declarava no prefácio: "Já há muitos anos que vem crescendo em mim a convicçáo de que é no jogo e pelo jogo que a civilização surge e se desenvolve" (HUIZINGA, 2007, s. p.). Logo em seguida, ainda no prefácio, afirma que é possível perceber indícios dessa crença em seus estudos desde 1903. O autor comprova-nos a sua crença-convicção com teses que não vamos trazer e discutir neste trabalho; basta afirmar que foi a partir do entendimento de algumas coordenadas de tal estudo, e de outros que com ele dialogam, que temos condiçôes de sugerir a relaçáo esboçada no parágrafo anterior. A atividade lúdica (homo ludens), tomada aqui como sinônimo de jogo e brincadeira, não apenas no período cronológico da infância, mas na experiência humana, e reconhecida da abertura ao fechamento da obra como uma categoria primária da vida, táo essencial quanto o raciocínio (homo sapiens) e a fabricaçáo de objetos (homo faber), também nos parece impulso para a inauguraçáo do processo de escrita acadêmica, que, então, além de estar ao lado da atividade intelectual (ou deveríamos escrever "racional"?), é capaz de motivá-la e suplantá-la. Sinalizamos aqui experiências e impressóes muito particulares, sobre as quais já estamos silenciando, todavia, cabe afirmar que é assim que temos percebido esses impulsos para a atividade intelectual ultimamente; logo, o movimento acerca da escrita aqui desenvolvida deu-se como a exemplo do parágrafo anterior.

Aceita a provocação da chamada, compreendida a sua amplitude e analisadas as diversas possibilidades de respostas que poderíamos oferecer a ela, concentramo-nos na seguinte ideia: há um modo de ler que resulta no gesto de fazer do livro morada, espaço de permanência, habitação, refúgio 
- algo bastante comum, uma sensação recorrente na leitura literária -, mas, e quando ele é tão caro ao leitor que acaba por registrar na escrita a experiência da morada que a leitura representou em algum momento ou estágio da sua história (de leitura)? Estávamos dispostos a olhar mais de perto a utilização da simbologia da casa, da moradia e a sua representação em diferentes escritas, entretanto, como viemos percebendo essa questâo nas leituras que fomos retomando, notamos que era necessário um arejamento por parte da nomenclatura, de modo que expressôes como "simbologia" e "representaçáo" demarcavam áreas e campos conceituais que náo temos intenção de adentrar aqui ${ }^{1}$. Por isso, é importante endossar que a intenção inicial era observar o "aproveitamento" ou a "utilizaçáo" da ideia de casa, moradia ou habitação, em determinadas escritas, pois quando tais recursos foram utilizados, a apropriação das expressóes ocorria por adesão, sobretudo afetiva e, talvez, observá-las assim aproxime-nos mais desse olhar primário, a nós tão importante. Mas também havia outra presença da casa, da moradia, nas escritas, conforme fomos mobilizando nossas memórias de leituras, aquela cuja utilização da imagem da casa não se vinculava a um livro, mas a outros elementos. Nesses casos, interessava-nos perceber que sentido tais elementos poderiam oferecer às casas nessas escritas e em que medida eles se aproximavam dos sentidos percebidos no aproveitamento dos lares.

Mesmo com um recorte frente a chamada, havia um universo a ser explorado, e nele foi preciso mais uma cisão: tanto nos estudos sobre a leitura, quanto naqueles sobre a literatura, tomando aqui segmentos diversos, como o infantil, juvenil, "adulto", o aproveitamento da ideia e do significado de casa é recorrente. Eis, então, o recorte do recorte: optamos por desenvolver algumas reflexóes a partir de Walter Benjamin (2002),

\footnotetext{
${ }^{1}$ Se viermos a utilizar as expressôes em questão, é por puro descuido. Aproveitamos a oportunidade para esclarecer que é uma opção nossa náo recorrermos ao Dicionário de símbolos (1989), de Jean Chevalier e Alain Gheerbrant, para trazer ao estudo um significado lá estabelecido à casa, à habitaçấo ou à moradia, por entendermos importante percebermos o significado que os autores arrolados na sequência dão aos elementos. Obviamente, já recorremos a ele em outras oportunidades e sabemos do potencial esclarecedor de seus verbetes e de toda a substância cultural e de tantas outras ordens ali depositadas. Mas, às vezes, surge como necessidade uma margem, um respiro, um olhar primário para algumas questôes. Há também o nosso entendimento de que as questóes que envolvem a cultura e simbologia e, por consequência, a linguagem escrita são intensas e marcadas por atravessamentos culturais que permitem que os significados que Chevalier e Gheerbrant estabelecem para casa, moradia e habitação já estáo, de certa forma, assimilados nas manifestaçóes dos autores aqui estudados. As mesmas consideraçôes, em certa medida, aplicam-se ao seminal A poética dos espaços (1989), de Gaston Bachelard. Entretanto, há quem perceberá mais relação no aproveitamento do estudo desse teórico na análise das obras mencionadas no fechamento do trabalho.
} 
Alberto Manguel (2010) e Michèle Petit (2009) e, para isso, retiramos de seus escritos teóricos fragmentos nos quais os autores fazem alusão ao livro como espaço de morada, habitação, e estabelecemos diálogos com outros fragmentos ou estudos dos mesmos autores, os quais ampliam a referida analogia. Nessa perspectiva, propomos associações bastante particulares que nossa área de estudo e docência permite realizar, à medida que nosso interesse volta-se particularmente para o livro de literatura infantil, bem como o leitor perceberá no nosso esforço em relacionar as consideraçóes de Benjamin (2002) aos estudos sobre o livro ilustrado contemporâneo.

A fim de apresentar já na abertura as obras das quais os fragmentos analisados foram retirados, apontamos: Reflexóes sobre a criança, o brinquedo e educação (2002), de Walter Benjamin; Uma história da leitura (2010), de Alberto Manguel e A arte de ler ou como resistir à adversidade (2009), de Michèle Petit. $\mathrm{O}$ investimento de nossa parte é demonstrar, percorrendo tais escritas no viés sinalizado anteriormente, que a leitura é uma casa e morada especialmente acolhedora para quem faz a experiência de um exílio qualquer, seja através da imigração, seja através dos acasos da vida. É sobre isso que a próxima seção tratará, e ela representa nosso esforço em juntar as peças e ajustá-las de algum modo para que, no final, alguma imagem possa ser visualizada. No fechamento, após retomar as reflexôes iniciais, a fim de apresentar os pontos de intersecçáo de modo mais objetivo, estendemos nossa escrita para apresentar, a partir de uma analogia que nos é importante e que se assemelha com a do quebra-cabeça - a do voo, recuperada de uma crônica-ensaio da pesquisadora Marta Morais de Costa (2006) -, as possibilidades de análise que, num primeiro momento, vislumbramos para a continuidade dessa escrita, depois da segunda seção.

\section{As moradas desejadas, as intuídas, as negadas e alguns diálogos possíveis}

Dadas as circunstâncias da elaboração deste estudo na seção anterior, poderíamos lançar mão de vários fragmentos para iniciar a escrita, vista a correspondência entre as consideraçóes dos três autores, uma vez que lançam mão da mesma alusão - a morada, a casa, a habitação, conforme já declarado. Entretanto, organizamos a seção, os pensamentos e as coordenadas a partir dessa declaração de Benjamin, e assim lançamos a primeira peça do quebracabeça:

O mundo que se revela no livro e o próprio livro jamais poderiam ser, 
de forma alguma, separados. Assim, junto com cada livro, também seu conteúdo, seu mundo, estava ali, à mão, palpável. Mas, igualmente, esse conteúdo e esse mundo transfiguram cada parte do livro. Queimavam dentro dele, lançavam chamas a partir dele; localizados náo somente em sua encadernação ou em suas figuras, estavam entesourados em capítulos e capitulares, em parágrafos e colunas. Você não lia livros, habitava neles, morava em suas linhas, e reabrindo-os depois de um intervalo, surpreendiase no ponto aonde havia parado (BENJAMIN apud MANGUEL, 2010, p. 25$)^{2}$.

Benjamin, já adulto, é capaz de perceber, no horizonte das experiências do leitor pré-adolescente e adolescente, a articulaçáo do livro enquanto objeto com o seu conteúdo, além do impacto que essa relação pode ter na recepção. É essa percepção que leva o leitor daquela época a encontrar um significado circunscrito no texto verbal e reconhecer certa força potencializada nele, mas que também se transmutava nas "partes do livro", para usarmos uma expressão do autor: no papel, fibra vegetal no formato de folha, na qual a escrita é materializada, por meio da tinta tipografada em formatos variados; na encadernação, que por economia vamos tomar por sinônimo de capa, cápsula protetora que, ao reunir, separa as páginas que compóem a obra; as figuras, que podem ser uma simples vinheta, ou servir para ilustrar um aspecto ou outro do texto ou, numa proposta mais ousada e, considerando, sobretudo, os livros contemporâneos para a infância, inaugurar uma relaçáo táo intensa que pode vir a subverter o sentido do próprio texto. É por perceber a interlocução em uma perspectiva criativa, em um diálogo incessante entre as partes do livro e o texto verbal, que ele acolhe o que Benjamin afirma: "O mundo que se revela no livro e o próprio livro jamais poderiam ser, de forma alguma, separados" (BENJAMIN apud MANGUEL, 2010, p. 25). Repetimos, propositalmente, com vistas a reafirmar a importância da declaraçáo e o quanto representa em termos de orientaçóes para pensarmos em determinados modos de ler e na circulação de obras literárias, considerando a literatura para a infância e a juventude e também o espaço que elas ocupam no ambiente escolar, função que essa escrita pode contribuir e para a qual as memórias de Benjamin apontam alguns contornos importantes.

Tomando a literatura infantil e juvenil como exemplo, não haveria lógica, considerando os projetos contemporâneos que esses dois sistemas

${ }^{2}$ Poderíamos recuperar a citação diretamente do texto de Walter Benjamin, intitulado A Berlin chronicle, entretanto, há um propósito em apresentar a citação a partir da obra de Alberto Manguel, conforme pode-se perceber no desenvolvimento do trabalho. 
têm apresentado, insistir na separação do "mundo que se revela do livro" - o conteúdo - do "próprio livro" - o objeto, ou a forma - sem querer estabelecer uma dicotomia simplista, mas que pode ser útil. Nesta área de produção artística, os projetos de literatura contemporânea para a infância denominados livro ilustrado ${ }^{3}$ correspondem justamente a esse desejo de não proceder com a separação acima comentada, muito pelo contrário, a proposta deste produto cultural é oferecer uma obra, produto de um processo criativo do qual participaram o autor do texto verbal, o ilustrador e o designer gráfico, bem como o coordenador editorial ou editor, ou ambos, quando a casa editorial dispóem dos dois profissionais. O processo criativo ao qual nos referimos é de intensa troca e desapego, no sentido de que nenhuma dessas frentes, que podemos chamar de linguagens, e nenhum desses profissionais têm superioridade em relação aos outros.

Projetos que partem desse princípio investem esforço intelectual e artístico justamente na fusão do conteúdo na forma e vice-versa, e o resultado é percebido quando o leitor consegue compreender essa transmutação, quando o resultado final permite entender, como fez o Benjamin adulto, olhando para o seu passado de leitor, que o conteúdo pode submergir, transfigurar em cada parte do livro e náo somente, como é natural e esperado, no texto verbal. Essas outras partes, que já náo nos parecem exatamente partes, tão fundidas que as percebemos em alguns projetos que temos visto nos últimos anos, continuam a queimar e lançar chamas de dentro e de fora dos livros ilustrados, objetos que queimam, ardem em significados e sentidos, à espera do leitor, como se a obra que se oferece à leitura aquecesse quem dela se aproxima, para ficarmos no campo semântico sugerido pelo autor.

Benjamin, que tem um número significativo de artigos sobre o livro e outros produtos culturais para a infância, já observou atentamente a

${ }^{3} \mathrm{O}$ conceito de livro ilustrado e, inclusive, a nomenclatura que adotamos encontra respaldo no seguinte conjunto de publicaçóes:

HUNT, Peter. A crítica e o livro-ilustrado. In: HUNT, Peter. Crítica, teoria e literatura infantil. Traduçấo de Cid Knipel. São Paulo: Cosac Naify, 2010. p 233-254.

LIMA, Renata Vilanova. Ilustraçóes em traços e manchas no Design no livro-ilustrado infantil brasileiro contemporâneo. Rio de Janeiro, 2012. 263 f. Tese (Doutorado em Design) - Programa de Pós-graduação em Design, Pontifícia Universidade Católica do Rio de Janeiro, Rio de Janeiro, 2012.

NAKANO, Renata Gabriel. Livro ilustrado: definiçôes, leitores e autores. Rio de Janeiro, 2012, 126 f. Dissertação (Mestrado em Letras) - Programa de Pós-Graduação em Letras, Pontifícia Universidade Católica do Rio de Janeiro, Rio de Janeiro, 2012.

NIKOLAJEVA, Maria; SCOTT, Carole. Livro ilustrado: palavras e imagens. Tradução Cid Knipel. São Paulo: Cosac Naify, 2011. 
relação da ilustração, em especial da cor com a subjetividade da criança, no ensaio Livros infantis velhos e esquecidos (2002), publicado originalmente na ediçáo natalina de 1924, de um jornal da cidade de Leipzig (Alemanha). Ele comentava, muito singularmente, a obra que dá título ao ensaio, de autoria de Karl Hobrecker (1924). Quem conhece essas escritas produzidas pelo autor, também chamadas de resenhas, inclusive na edição que estamos utilizando, sabe que ele parte de algo estabelecido no cotidiano, como um livro recém-lançado à época ou uma exposição de brinquedos antigos visitada para, em seguida, abordar as questôes de modo mais substancial, como o faz no ensaio, no que se refere à ilustração e outros temas bastante caros à literatura para a infância e ao livro ilustrado, considerando que ele discorre sobre tais temas na metade da primeira metade do século XIX.

O movimento que sinalizamos pode ser percebido, por exemplo, quando Benjamin (2002), em determinado momento da reflexão em destaque, acrescenta, e diz-se feliz por isso, à compilação de "livros infantis velhos e esquecidos" de Hobrecker, uma ediçáo sem data de Fábulas de Esopo, publicada por H. F. Müller, em Viena, a qual faz parte da sua coleção particular. Em seguida, o articulista segue para consideraçôes históricas acerca das diferenças do livro colorido do século XIX, do seu presente contemporâneo, em contraponto às gravuras em preto e branco dos tempos anteriores. É assim que vai colocando as diferenças entre as tais gravuras e as ilustraçóes do estilo "biedermier", que articulavam preferencialmente o carmim, o laranja, ultramarino e um verde brilhante. De uma explanação que mobiliza informaçóes pontuais articuladas em um jogo de oposiçáo, de fácil assimilação, que conta com a ajuda de notas de pé de página para elucidar termos do alemão e dados específicos sobre as técnicas de ilustração em questáo (mimos do tradutor), o autor leva o leitor, linha a linha, a adentrar na percepção do impacto que a ilustração, mais especificamente a cor, tem na subjetividade da criança, e, no fechamento, pontua que

[...] os livros infantis não servem para introduzir os seus leitores, de maneira imediata, no mundo dos objetos, animais e seres humanos, para introduzilos na chamada vida. Só aos poucos o seu sentido vai se constituindo no seu exterior. A interioridade dessa contemplação reside na cor, e em seu meio desenrola-se a vida sonhadora que as coisas levam no espírito das crianças. Elas aprendem no colorido. Pois na cor, como em nenhum outro lugar, a contemplação sensual e não nostálgica está em casa (BENJAMIN, 2002, p. 62, grifo nosso).

Julgamos importante recuperar essa reflexão do autor, visto que 
estamos tratando dos elementos que compóem o livro ilustrado para a infância, considerando a interseção desses elementos. Perspectiva já sinalizada neste estudo, a ilustraçáo componente fundamental do conjunto e a cor, um dos elementos que, articulados aos demais, completam e potencializam os aspectos visuais do livro ilustrado. No fragmento anterior, pinçado da obra de Alberto Manguel, parece que Benjamin (2002) não se ateve minuciosamente a questôes relacionadas à ilustração, a julgar pela escolha da expressão "figura" para se referir às imagens dos livros que lia na infância. Contudo, ele tratou do tema, e em perspectivas arrojadas, que virão, no século seguinte, encontrar correspondência nos estudos sobre o livro ilustrado.

Ainda sobre as afirmaçôes do autor, o tempo subjetivo próprio da criança, que tem seu universo interior provocado, sobretudo, pelo potencial da cor na ilustração, precisa ser respeitado, pois a exteriorização da experiência em questão não é uma resposta imediata, e não pode ser exigida, calculada e prevista. Está aí uma coordenada que os mediadores de leitura precisam levar em consideração, quando pensam nas atividades posteriores ao encontro do leitor com a obra nas práticas de leituras das escolas e das bibliotecas. Elas precisam ser especialmente delineadas de modo a respeitar o tempo e o movimento interno do qual nos fala Benjamin (2002). O investimento maior, sugerimos, na orientação de elaboração de práticas de leituras que orientamos há um bom tempo no Ensino Superior, deve ser nos momentos que antecedem o encontro e no encontro em si. Potencializados esses momentos, é hora de maneirar e entender, para daí acreditar, que o silêncio também pode ser resposta a uma provocação do campo da literatura, tomada aqui pelo livro ilustrado.

Benjamin (2002), que antes nos relatava uma imersão tão intensa em determinadas obras que lia na infância a ponto de representarem espaços para serem habitados, "morados", afirma, no final do último fragmento transcrito, que a cor é lugar único, "casa", para a contemplação sensual. Visto que a expressão "casa" e a projeçáo de seus sentidos nos interessam nesta escrita, apesar de Benjamin (2002) não ter realizado essa dinâmica, na ocasião, em relação aos livros, cabe estender o comentário e lançar o olhar para a questáo. A casa, ali, aparece como contorno, espaço demarcado de acolhida e proteçáa, como também apareceu no outro fragmento do autor. Quanto à sensualidade que envolve a contemplação, caracterização talvez desconcertante para alguns, é a resposta do leitor frente à cor, que é, por natureza, provocante; mesmo as mais discretas estão a nos estimular, a oferecer margem para jogos de diversas naturezas, possibilitando inaugurar 
ideias que se insinuam sensuais, reptantes, e que, por isso, podem ser casas. Nesse processo, a cor coloca-se, sem constrangimento, como elemento a ser contemplado com sensualidade no conjunto que ela ajuda a formar naqueles livros sobre os quais Benjamin (2002) comenta no ensaio em questão.

$\mathrm{O}$ que merece ser levado em consideração, no caso de Benjamin (2002), é que só um livro com esses atributos mereceria ser habitado, livrocasa que conjuga forma e conteúdo e os coloca equilibrados, em troca, mutação, ou que apresentasse algum esforço em colocá-los em sintonia. Mereciam, livros assim, serem habitados em sua estrutura geral e em suas linhas, como bem ele afirmou. Alberto Manguel, quando introduz a voz (no caso, escrita) de Benjamin (2002) na abertura de Uma história da leitura (2010), provocativamente intitulada "A última página”, o faz para demonstrar a similaridade de pensamentos entre eles. A ideia que Manguel (2010) procura reforçar quando recorre à Benjamin (2002) é a de que, "[...] na infância, como em boa parte da adolescência, o que os livros me contavam, por mais fantástico que fosse, era verdade no momento da leitura tão tangível quanto o material de que o próprio livro era feito" (MANGUEL, 2010, p. 25). Seis linhas acima, o autor havia declarado: "Cada livro era um mundo em si mesmo e nele eu me refugiava" (MANGUEL, 2010, p. 25). Sem dúvida, o diálogo entre eles é pertinente e já demonstramos os motivos, que são testemunho de como ele reverberou em nós e mobilizou outros textos, outras questôes e aspectos teóricos, como os estudos do livro ilustrado contemporâneo, que, por opção, não vamos expor trazendo aqui citaçôes diretas como já fizemos em outros trabalhos, até mesmo porque nem é esse o propósito.

Outro texto mobilizado na perspectiva de que tratávamos remete-nos novamente a Benjamin, que em Rua de mão única-extratos permite perceber na expressão "extratos" do título, a presença dos fragmentos da obra Rua de mão unica $a^{4}$ na perspectiva que se anuncia no título da coletânea da qual a transcrevemos, a saber, Reflexóes sobre a criança, o brinquedo e a educação:

\section{Ampliaçóes}

CRIANÇA LENDO. Na biblioteca da escola recebe-se um livro. Nas

\footnotetext{
${ }^{4}$ Necessário registrar que temos conhecimento da obra em questão, incluída no segundo volume das obras escolhidas de Walter Benjamin, publicada pela Editora Brasiliense, em 1998, cujas informaçôes vamos inserir apenas nas "Referências" para evitar tanto detalhamento acerca das fontes, o que pode render aborrecimento aos leitores. Contudo, a traduçấo de Marcus Vinícius Mazzari para o texto original é mais apropriada, vistas as consideraçôes que vamos apresentar na sequência.
} 
classes inferiores os livros são distribuídos. Vez por outra, apenas se ousa expressar um desejo. Frequentemente vê-se com inveja livros almejados caírem em outras mãos. Por fim recebeu-se o seu. Durante uma semana o leitor esteve entregue à agitaçáo do texto, que suave e secretamente, densa e ininterruptamente, envolveu-o como flocos de neve. Adentrou-se assim o interior do livro com ilimitada confiança. Silêncio do livro que atraía mais e mais. Cujo conteúdo não era assim tấo importante, pois a leitura ainda caiu na época em que se inventaram na cama as próprias histórias. A criança vai rastejando esses caminhos semi-encobertos. Durante a leitura ela tapa os ouvidos; a sua leitura fica sobre aquela mesa demasiado alta e uma mão está sempre sobre a página. Para a criança, as aventuras do herói ainda sấo legíveis no torvelino das letras, com figura e mensagem na agitação dos flocos. Sua agitação paira sobre a atmosfera dos acontecimentos e todas as figuras bafejam-na. A criança mistura com as personagens de maneira muito mais íntima do que um adulto. É atingida pelo acontecimento e pelas palavras trocadas de maneira indizível, e quando a criança se levanta, está inteiramente envolta pela nele que soprava da leitura (BENJAMIN, 2002, 104-105, grifo do autor).

Apesar de abandonar a primeira pessoa utilizada no fragmento anterior, ao narrar a experiência de uma criança lendo, o autor deixa perceber, e sem que seja necessário uma transposição para a realidade da simbologia que envolve o desejo de morar ou habitar em um livro - mas ao mesmo tempo sem mencionar expressóes que denotem diretamente essa vontade -, como o ato de ler estimula, incita e provoca a criança, que faz do livro um espaço no qual projeta, além dos sentidos, o amplo universo que a leitura mobiliza. Há uma entrega tâo honesta, tâo plena percebida no relato do autor que, já não sei se, quando adultos, conseguimos nos envolver com a ficçáo tal como fez o leitor do excerto, sobretudo, porque lemos quase sempre condicionados pelas circunstâncias que a crítica especializada já demarcou ou, então, para poder lançar sobre as obras o olhar inicial que nos cabe na condição de pesquisador, também vinculado pela herança dos estudos da área em que nos encontramos.

A criança, quando lê, a exemplo do leitor do fragmento, está sempre em um movimento de ampliação, já sinalizado no título do breve relato, porque se oferece espaço (morada) para dilataçáo das ideias e principalmente das coordenadas subjetivas que o texto literário oferece-lhe. A criança focalizada pelo autor tem reações legítimas em direção ao texto e as viveu intensamente no período em que o livro esteve com ela. Impossível náo se lembrar da protagonista narradora de Felicidade clandestina (1998), conto de Clarice Lispector, e, na comparação, lembrar que à menina devoradora de livros foi oferecido o exemplar de Reinaçóes de Narizinho, de Monteiro 
Lobato, por quanto tempo ela quisesse. Sobre essas circunstâncias, a narradora declara: "Valia mais do que dar o livro: 'pelo tempo que eu quisesse', é tudo que uma pessoa, grande ou pequena, pode ter a ousadia de querer". (LISPECTOR, 1998, p. 12, grifo da autora). Ao menino de Benjamin coube uma semana, tempo demarcado, nem por isso vivido com menos intensidade e entrega. O período estabelecido foi caracterizado pelo autor como agitado, e todo um ritual foi sinalizado no envolvimento do leitor com a obra. Nota-se o deslumbramento próprio das descobertas e descerramentos quando o leitor permite que o texto o envolva "suave e secretamente, densa e ininterruptamente", como flocos de neve. Há muito para se observar no provocante relato, todavia, trazendo mais objetividade à escrita, pontuemos a escolha do verbo "adentrar" como importante na perspectiva de quem também está impelindo no espaço que o acolheu como morada durante aquela semana, morada silenciosa, como ficamos sabendo, silêncio que atraía o menino, quando muitas crianças o rejeitam.

É desconcertante, decepcionante até para os mais entusiastas, entender que o conteúdo do livro não era o mais importante, frente, justamente, às histórias contadas na cama. E sobre isso, nossa escrita poderia percorrer outro caminho de agora em diante, que é o de demonstrar o impacto da narração ou da contaçáo das histórias lidas ou inventadas na vida subjetiva e intelectual da criança, bem como o prejuízo da sua falta, área para a qual inclusive Benjamin ontribuiu com o seu ensaio $O$ narrador, consideraçóes sobre a obra de Nikolai Leskov. Náo vamos enveredar a escrita e as reflexôes por esse caminho, mas uma pesquisa acerca do trabalho artístico e acadêmico, quando for o caso, de Benita Prieto, Celso Cisto, Giuliano Tierno (Giuliano Tierno de Siqueira), Léla Mayer (Valéria Neves Kroeff Mayer), Augusto Pessôa, Aline Cantia, Danielle Andrade, Josiane Geroldi, Cléo Busatto, Roger Castro (Roger Andrei de Castro Vasconcelos) e Alice Oliveira, para citar pessoas com as quais mantemos vínculos e que utilizamos como referência sobre a temática, tanto na docência quanto na pesquisa.

O que faria, então, o leitor envolver-se tão intimamente e estabelecer o tom ritualístico que caracterizávamos como íntimo e que lembra o gesto da ocupação de um espaço que ele quer fazer morada? Aí já está a resposta: justamente o gesto em si, a possibilidade e a necessidade de o fazer, para além da temática e do conteúdo, o encontro, no livro, de um espaço que assegura o pertencimento, a acolhida. É isso que, possivelmente, faz com que o leitor de Benjamin náo abandone o livro, pelo contrário, invista tempo, intelectualidade e todo o mais que percebemos na empreitada. A leitura que realiza sozinho, frente às experiências com a história narrada 
ou contada, é sinalizada pelo narrador como uma "criança rastejando esses caminhos semi-encobertos". O verbo rastejar prolonga a movimentação de quem adentrou no espaço e, com as suas condiçóes, continua a travessia. Talvez, o significado e a carga visual do verbo nos remetam à fragilidade e ao desiquilíbrio próprios de quem ainda não articula com firmeza com os dois pés e que, por isso, encontra os caminhos semi-encobertos; todavia, mesmo observando esse sentido, que pode ser levando em consideraçáo no contexto, por estar originalmente circunscrito no verbo, o entusiasmo e a perplexidade da jornada em direção à especulaçáo pelo espaço náo são anulados por esse entendimento.

O envolvimento com o herói é genuíno da infância, e Benjamin o apreende ainda na decodificação das letras, tamanha é a adesáo do leitor; o aproveitamento simbólico da neve, no enredo, para sinalizar a aproximaçáo, o consentimento e uma espécie de transmutação, no fechamento, do leitor em personagem, é um recurso literário sofisticado, que a tradução aqui utilizada soube manter. Embora essas questôes não impliquem na argumentação que nos dispomos a desenvolver, mereciam esse destaque. Quanto à experiência que, supomos, o breve relato de Benjamin exemplifica, ela pode elucidar o que vem a ser, também para Manguel, a experiência de habitar ou morar nos livros, bem como o historiador declara:

Como meu pai era diplomata, viajávamos muito. Os livros davam-me um lar permanente, e um lar que eu podia habitar exatamente como queria, a qualquer momento, por mais estranho que fosse o quarto em que tivesse de dormir ou por mais ininteligíveis que fossem as vozes do lado de fora da minha porta. Muitas vezes, à noite, eu acendia a lâmpada de cabeceira e, enquanto a babá trabalhava em sua máquina de costura elétrica ou dormia roncando na cama ao lado, tentava chegar ao fim do livro que estava lendo e, ao mesmo tempo, retardar o fim o mais possível, voltando algumas páginas, procurando um trecho de que gostara, verificando detalhes que achava terem me escapado [...] (MANGUEL, 2010, p. 24).

A experiência do deslocamento físico-geográfico parece cara ao menino Manguel, e é justamente a partir dela que ele, já historiador da leitura, organiza suas memórias, as quais, conforme percebemos, vão projetar no livro o espaço seguro do lar, da residência. Importante notar que, acerca dessas memórias, ele vai declarar na sequência, que se "refugiava" nos livros, afirmaçáo que já aproveitamos em forma de citaçáo neste estudo. Essas circunstâncias permitem-nos relacionar a condição de Manguel a deslocamentos contemporâneos que levam pessoas a buscar o Rio Grande 
do Sul como espaço geográfico, experiência que podemos expressar pelo viés da observação e da empatia. Não temos intenção nenhuma de tirar o lugar de expressão daqueles que terão suas subjetividades intuídas nesta escrita e, se o fizemos, é por empatia e até como homenagem, bem como registramos na dedicatória deste artigo, que se encontra, conforme orientaçóes de formatação do periódico, no fechamento do trabalho.

Assim, tomamos por referência os refugiados que atualmente chegam ao país, a precariedade de suas condiçóes - materiais e emocionais -, ou os imigrantes dos países africanos, em busca, quase sempre, de melhores condiçóes econômicas, já que os conflitos civis, nos seus territórios, não são declarados. Contudo, as circunstâncias que o distanciamento dos familiares, a falta de melhores condiçôes financeiras, o subemprego a que são obrigados a se submeter e o racismo (velado e, ultimamente, descaradamente assumido) com o qual são recebidos e tratados nos diversos Estados brasileiros, talvez, forjem sua subjetividade, uma condição tão precária quanto a dos refugiados. Manguel, por sua vez, deslocava-se em outras condiçóes, pelo menos no que se refere às questôes econômicas, todavia, é importante perceber que, se suas memórias do período sinalizam que é nos livros que ele encontra um lugar permanente, tais movimentos geográficos também matizavam nele alguma impressão de não pertencimento no plano físico, arquitetônico, que ele procurava equalizar justamente nos livros e na literatura neles inscrita. Enquanto era necessário viver externamente em lares e quartos estranhos, frequentemente substituídos, o livro apresentava-se como lar permanente, fixo, seguro e sempre disponível; mesmo que as obras fossem se alterando, é na materialidade do objeto em si que ele busca essa segurança.

Do modo exposto anteriormente, aproximamos a impressão que nossa empatia permite perceber do deslocamento físico e seu desdobramento na subjetividade dos refugiados e os imigrantes que chegam ao Brasil, mais especificamente ao Rio Grande do Sul, da experiência que essa mesma empatia permite perceber nas mudanças de país que levavam Manguel a desapegar, quem sabe muitas vezes repentinamente, das casas e dos quartos, apegar-se aos livros e projetar neles a segurança que já náo encontrava no limite das paredes, do chão e do telhado - propriamente ditos. Muitas circunstâncias colocam os refugiados, os imigrantes e Manguel em condiçóes diferentes, temos noção disso, contudo, pedimos uma exceção para a aproximaçáo. Quantos filhos dos refugiados e imigrantes (e mesmo os adultos nessas condiçôes) já não fizeram dos livros sua morada, vista a precariedade e a vulnerabilidade das condiçóes nas quais se encontravam? Desejável, seria, se tais crianças, adolescentes, jovens e adultos encontrassem 
um livro, preferencialmente literário, para projetar nele sua morada quando lhes falta tanto, em tantos sentidos e aspectos, e se refugiassem e imigrassem para um espaço simbólico. Desejável, também, seria que a voz materna e paterna ou de qualquer familiar responsável pelo encaminhamento cultural e afetivo dos pequenos não tivesse cessado as manifestaçôes poéticas e narrativas oralizadas, que poderiam representar acolhida, principalmente nesses contextos.

Michèle Petit investigou diversas questóes acerca do universo da leitura por orientaçóes quase sempre inspiradas pela antropologia, mas nunca limitadas a ela. A sua contribuição aos estudos da leitura é imensa e só a consulta integral das obras de sua autoria utilizadas aqui pode oferecer tal dimensáo aos interessados no tema e na abordagem. No recorte e na perspectiva que assumimos nessa escrita, alinhamos o nosso entendimento às reflexôes presentes no fechamento de $\mathbf{A}$ arte de ler: ou como resistir à adversidade (2009), onde a autora mobiliza-se para circunscrever significados nos gestos de leitura, muitas vezes de adolescentes e jovens, em contextos adversos - situaçóes de violência, de guerra, recessóes econômicas, deslocamentos populacionais etc. Esse último elemento permite-nos o encaixe (para recuperar a ideia já quase esquecida do quebra-cabeça lá do início do texto) das colocaçóes da autora nesse espaço do artigo. Muitos desses leitores são latino-americanos, alguns brasileiros, e suas histórias de leitura chegaram até a pesquisadora por meio de relatos dos mediadores de leituras. A reflexão para a qual fixamos os olhos de imediato utiliza a analogia do livro como espaço de moradia, em uma perspectiva talvez já intuída em Benjamin e Manguel, mas que Petit (2009, p. 284) coloca nessas palavras:

\footnotetext{
Um local de acolhida é igualmente encontrado: os livros lidos são moradas emprestadas onde é possível se sentir protegido e sonhar com outros futuros, elaborar uma distância, mudar de ponto de vista. Para além do caráter envolvente, protetor, habitável, da leitura, uma transformação das emoçóes e dos sentimentos, uma elaboração simbólica da experiência vivida tornam-se, em certas condiçôes, possíveis.
}

Embora a experiência que envolve a leitura literária seja uma circunstância particular, mesmo em práticas de leitura coletivas, já que o texto tem um impacto muito específico em cada leitor, podemos imaginar uma percepção aproximada de aspectos estéticos e subjetivos por leitores que vivem situaçóes adversas, como as que nos levaram o diálogo com Petit: os contextos de deslocamentos populacional que sinalizamos a 
partir da percepçáo dos refugiados, dos imigrantes, sobretudo dos países do continente africano, e de Manguel criança, condicionado às mudanças seguidas e repentinas da família, para quem o adjetivo "populacional" talvez nem combine. A autora sinaliza o livro como espaço para a transformação das emoções e para a elaboração simbólica dos sentimentos, também uma justa e necessária função que justifica a analogia e a amplia, quem sabe, até permitindo pensá-la como consultório, clínica, hospital e, mesmo, prontosocorro. Pensá-la, sim, mas se a própria autora não o faz no nível do discurso, da linguagem, em outro momento, conforme se verá na consulta da obra ou na sequência de nossa escrita, deve haver motivo para isso ${ }^{5}$. Embora o capítulo Leitura e exilio, o sétimo, seja o mais importante, na perspectiva que aqui encaminhamos o raciocínio, uma afirmação do terceiro capítulo, intitulado Simbolização e narrativa, é relevante para compreendermos a demanda que a pesquisadora vai levantar acerca dos recursos que a literatura e a arte em geral podem oferecer àqueles que vivem o limite da experiência do deslocamento populacional e do seu impacto nos diversos níveis, o que é possível perceber subjetivamente:

Não importa o meio onde vivemos e a cultura que nos viu nascer, precisamos de mediações, de representaçóes, de figuraçóes simbólicas para sair do caos, seja ele exterior ou interior. $\mathrm{O}$ que está em nós precisa primeiro procurar uma expressão exterior, e por vias indiretas, para que possamos nos instalar em nós mesmos. Para que pedaços inteiros do que vivemos não fiquem incrustados em zonas mortas do nosso ser. De outra forma. Não temos condiçōes de fazê-lo (PETIT, 2009, p. 115).

Reconhecidas as diferenças entre a cultura herdada pelo tempoespaço do nascimento e os primeiros anos da existência e aquela que é a experiência do meio e das relaçóes que avançam para além da infância, percebemos aqui, mais uma vez, sua comunháo. Antes, pelo discurso de Petit (2009), que se refere às vivências dos leitores aos quais suas pesquisas buscou identificar sentidos; depois, pelo nosso, a partir da demanda deste estudo em seu estágio final, no que se refere a um gesto de compreender o que poderia se passar na subjetividade de refugiados, sejam eles palestinos ou de qualquer outro país, imigrantes, sejam dos continentes africanos ou de qualquer país, e Manguel, uma criança a quem, mesmo descendente de uma família em circunstâncias econômicas diferentes das anteriores, viveu também a experiência do deslocamento, quando, se dependesse dele, quem

\footnotetext{
${ }^{5}$ Sugerimos o aprofundamento da questão a partir da consulta das páginas 27 e 28 da obra em
} questấo, na edição informada nas "Referências", nas quais a autora trata sobre a biblioterapia. 
sabe, não se abriria mão da estabilidade do endereço fixo.

A questão é reconhecer a necessidade intrínseca do ser humano - que o conjunto de expatriados mobilizado aqui potencializa - de procurar na expressão literária a representação, a "figuração simbólica" do seu mundo interior, uma projeção externa dele, por isso mesmo "mediaçáo", nas palavras da autora, para conseguir voltar novamente o olhar para dentro de si com novas possibilidades de descobertas e outras projeções de significados. É um processo que encontra correspondência ou inspiração na Psicanálise e que, enquanto dinâmica, já foi explorado por outros estudos da leitura ${ }^{6}$, contudo, no caso de Petit, ele foi concebido no campo da Antropologia, com todas as interlocuçóes que a temática da leitura exige.

Para além dessas informaçóes, protocolares a nosso ver, mas que podem indicar caminhos paralelos aos que percorremos, a afirmação da pesquisadora dá margem para que o capítulo considerado aqui como o mais adequado (haja vista as relaçóes entre o exílio - desterro do espaço no qual se gostaria, de fato, de estar presente fisicamente - e a representação dos livros enquanto espaços de acolhida, morada e do processo sobre o qual tratávamos anteriormente) possa ser compreendido nas coordenadas que nos parecem mais importantes. A afirmação recuperada da parte inicial da obra dá margem, por exemplo, para o leitor compreender com mais amplitude afirmaçóes como a que transcrevemos a seguir, bem da verdade, o parágrafo que fecha o capítulo Leitura e exílio, não propositalmente, e o significado que as expressóes que nos propomos a observar neste estudo ganham no contexto da pesquisa de Petit (2009, p. 266):

\footnotetext{
Os livros são hospitaleiros e nos permitem suportar os exílios de que a vida é feita, pensá-los, construir nossos lares interiores, inventar um fio condutor para nossas histórias, reescrevê-las dia após dia. E algumas vezes eles nos fazem atravessar oceanos, dão-nos o desejo a força de descobrir paisagens, rostos nunca vistos, terra onde outra coisa, outros encontros serão talvez possíveis, abramos então as janelas, abramos então os livros.
}

Além do exílio geográfico, a autora sinaliza que o livro, supomos o literário, tem potência para se fazer morada simbólica - "interior". Vejase, entáo, a importância de termos recuperado a declaração da parte inicial da obra. Quando a autora lança mão do verbo "reescrever", não é exatamente para caracterizar, nesse parágrafo, o ato da escrita-reescrita

${ }^{6}$ A saber, inicialmente, a Estética da recepção e a Teoria do efeito estético, encabeçados por Hans Robert Jauss e Wolfgang Iser, respectivamente. 
em si, mas uma atitude percebida na leitura que é a da possibilidade de dar um contorno táo particular ao texto a ponto de caracterizá-lo como uma possibilidade de reescrever, ou simplesmente perceber neles as suas próprias histórias. O impulso de atravessar oceanos, a força que desencadeia desejos de descobertas; desbravamentos estão ali, naquela casa, moradia, já dissolvida na escrita na autora, já que ela permite simbolizar suas partes em outra perspectiva, desdobramento da primeira, a janela, outra possibilidade para pensar a representação do livro, da literatura, e dos movimentos de reconstrução que eles podem simbolizar.

Um último comentário que explica a nossa motivação na associação entre os refugiados, os imigrantes e Manguel foi a notícia de que algumas entidades assistenciais da Serra Gaúcha/RS mobilizaram-se para oferecer cestas básicas aos refugiados e imigrantes que enfrentavam, além das dificuldades cuja condição econômica já lhes impunha, o estado de calamidade que se potencializou em proporçóes absurdas na pandemia da COVID-19, que teve início em 2020 e se encontra pior no início de abril de 2021, período em que o manuscrito retornou para a revisão. E a essas cestas básicas, foram acrescentados livros. Isso diz muito naquela região, povoada por imigrantes europeus, na sua grande maioria italianos, para quem o alimento, em si, é simbólico e materialmente inserido na sua cultura como sinal de resistência, continuidade (bem como em tantas culturas). Trocá-lo pelo livro diz muito, e oferecê-lo como um gesto de ajuda em momento táo complexo fez-nos pensar que, às pessoas que lessem aquelas histórias (na sua maioria, narrativas), independentemente da idade - embora tenhamos a tendência de um olhar especial à literatura de recepção infantil -, foi também oferecida morada; e também desculpas, acreditamos, pois, na mesma região - o que não significa que estejamos falando das mesmas pessoas -, houve um movimento, bem recente, por sinal, para impedir a entrada a refugiados imigrantes em algumas cidades.

\section{Para fechar a porta e espiar pela janela}

Para podermos, agora, levantar algumas questóes um pouco deslocadas do objetivo central do estudo, lançamos ideias conclusivas em diversos momentos da escrita na seção anterior. Mesmo assim, à guisa de conclusóes, é importante afirmar que, na tentativa de compreender a utilização dos elementos casa, morada, moradia e outros sinônimos atribuídos ao livro nas experiências de leitura dos autores escolhidos, particularidades de cada 
autor, bem como na adesão à analogia, como foi exposto, tais movimentos exigiram expandir o olhar para além dos fragmentos nos quais as expressóes em questáo estavam inseridas e para outros estudos desses autores, o que permitiu também avançar nas interlocuçóes e nas reflexóes. É o caso de Benjamin - só para ilustrar a questão -, que memoriza a experiência da leitura e já a assume como um estado de habitação e moradia, sinalizando, inclusive nos verbos conjugados do pretérito ("habitava", "morava"), que aquilo era recorrente. Todavia, para ele, expor essa experiência de morar no livro implica também expor como é esse livro que o acolhe e o faz querer permanecer por algum tempo. Como demonstrado no início da seção anterior, esse modo de Benjamin se manifestar, mobilizou (pelo menos a nós) questóes teóricas caras a uma área de estudo que visitamos com frequência. Quanto ao compartilhamento de sentidos no aproveitamento da expressão casa e seus sinônimos ao fazer alusão ao livro, ele é evidente nos três autores, conforme demonstramos.

Marta Morais da Costa (2006), em crônica-ensaio seguidamente mencionado por nós em trabalhos acadêmicos, desde que ele foi publicado na coletânea Mapa do mundo: crônicas sobre leituras, usa uma metáfora inteligente para se referir à leitura: "A atividade leitora consiste num salto sem paraquedas e sem solo onde adentrar. A única certeza é a do voo e do mapa desenhado pelo texto" (COSTA, 2006, p. 159). Há muitas questóes acerca da leitura, mobilizadas nessas linhas, mas vamos explorar a utilização da ideia ou da imagem do voo sem paraquedas para sinalizar a ampla margem de imprecisão (que só no final se reverterá em descoberta) com a qual que o leitor lida, principalmente na leitura literária. Costa (2006) faz-nos pensar também no impulso do arremesso daquele que se lança, sem paraquedas, somente com o mapa e o desejo do percurso. Nem sempre nos lembramos de dizer, mas, lá de cima, não se percebe todo o caminho e, principalmente bem no início do percurso, ele parece difuso, nebuloso, apresentando bifurcaçóes que abandonamos conforme vamos descendo. Segundo a autora, nem solo o leitor possui, é no mapa e no exercício do seu deciframento/travessia que reside todo o esforço.

Escrever, mesmo que em um exercício náo literário, é muito parecido com esse movimento que Costa (2006) manifestou na metáfora em questáo, e o tanto de improviso e flexibilidade que há na atividade em si nos fez citar, na abertura, Huizinga (2007), e seu Homo ludens, que agora retomamos para reafirmar o quanto de jogo, atividade lúdica, provocativa, há na escrita. A entrega e a gratuidade percebida na criança que joga, brinca, vive a atividade lúdica plenamente também pode ser observada em quem 
assume a montagem do quebra-cabeça que representa a construção de um texto, cujo aspecto lúdico e prazeroso estáo justamente em proceder com o mínimo de conhecimento na área, alguma coerência nas ideias e disponibilidade para perceber os movimentos (intelectuais, cognitivos e subjetivos...) que o jogo impóe quando são assumidas algumas regras, teimosamente se subverte outras e se cumpre com entusiasmo a montagem até que se considere, também dentro do tempo disponível, que as peças foram encaixadas a contento, embora nem todas as que separamos para o jogo, no impulso primário da brincadeira, foram utilizadas, conforme já mencionado na abertura do trabalho: veredas visualizadas logo no impulso do voo sem paraquedas, mobilizadas, mas abandonadas à medida que fomos descendo rumo ao mapa que, de fato, construímos.

Mas é sobre esse desenho inicial que queremos informar no fechamento da escrita, pois acreditamos importante sinalizar nosso roteiro: lá de cima, no impulso do voo, e com as obras separadas no chão de nossa biblioteca, ainda na escolha das peças com as quais procederíamos à montagem do quebra-cabeça. Depois dos autores aqui apresentados na seção anterior, partiríamos para uma reflexão sobre a declaraçáo de Monteiro Lobato: "Ainda acabo fazendo livros onde as nossas crianças possam morar". Ela faz parte de uma carta endereçada à Godofedro Rangel, escrita em sete de maio de 1926, no Rio de Janeiro, que se encontra na obra A barca de Gleyre, que compila quase quarenta anos de correspondência de Lobato e Rangel, conjunto que se considera, na literatura brasileira, um dos mais extensos testemunhos epistolares que veio a público ${ }^{7}$. A ideia era perceber como esse projeto foi levado adiante por Lobato, de modo geral no seu empreendimento literário, mas também observar como o aproveitamento da casa como espaço simbólico e como espaço físico - o livro às avessas -, aparece em algumas de suas obras.

$\mathrm{Na}$ sequência, abordaríamos o aproveitamento do livro como representação de morada em Lygia Bojunga, percebendo como ela realizou isso no seu projeto literário e editorial, (do prisma de uma obra que não chegamos a escolher), um modo de reverberar a máxima de Lobato. Havíamos separado para a empreitada uma tese, bem da verdade, um "romance em forma de carta”, endereçada à Lygia Bojunga, que percorre toda a produção literária da autora, em vieses propositalmente labirínticos, que lembram o

\footnotetext{
${ }^{7} \mathrm{~A}$ referida obra já recebeu várias ediçôes, inclusive está incluída na publicação de suas obras completas, o que leva a perceber a importância da correspondência de Lobato frente a sua produção literária propriamente dita. Vamos incluir nas "Referências" a edição física que possuímos.
} 
fluxo de consciência da escrita intimista, mas que se encontram em vários pontos, quando a autora, que tem domínio do que escreve, deseja. Trata-se de Para Lygia Bojunga, a mulher que mora nos livros, de Ana Letícia Pires Leal Câmara. Na escrita, ela percorre livro a livro da autora, percebendo, ora intuitivamente, ora com o rigor científico que uma tese exige, como que Bojunga, que acaba por se transfigurar personagem de sua obra, tomada aqui, pelo conjunto, que fez de seus livros morada, pois, entendem, a pesquisadora e a autora, que, antes de ser morada para o leitor, é preciso habitar neles. Só que, pelo modo que é construído, pelo entrecruzamento de vozes que apresenta e pelo que também nos oferece enquanto ficção, a escrita de Ana Letícia Pires Leal serviria de fundamentação teórica e também de material de análise.

Dessas referências bem pontuadas na história da literatura infantil e juvenil brasileira, que náo temos problema nenhum em visitar, partiríamos para a análise, na mesma perspectiva e nos mesmos sistemas literários, de obras publicadas na última década: a primeira seria a narrativa "Casa de consertos", da escritora Eloí Bocheco, publicada em 2012, e ilustrada por Walther Moreira Santos. Nela, há o aproveitamento do tom afetivo e poético manifestado no enredo e na linguagem e a transfiguração do espaço físico e simbólico de uma casa que se propóe ser espaço de conserto de brinquedos, metáfora sutilmente provocativa que encontra desdobramentos importantes, principalmente no período que estamos atravessando no país. Na sequência, concentraríamos nossa análise na coletânea de poemas Um livro para a gente morar, que tem seleção e organização de Sílvia Oberg e ilustraçóes e projeto gráfico de Daniel Cabral, publicada em 2018, cujo título já anuncia o porte do empreendimento. A obra apresenta um conjunto de poemas escolhidos pelo modo direto ou indireto como flertam com a temática da casa, da moradia, ou do desejo de habitar em um livro e, por isso, só a experiência da leitura já se torna arrebatadora. Todavia, para os poemas, Daniel Cabral preparou um livro que se insinua casa potencialmente, no qual o projeto gráfico e as ilustraçóes promovem o processo criativo sobre o qual falávamos, inspirados em Benjamin no início do artigo.

A menina que morava no sino, de Celso Gutfreind, publicada em 2020, seria analisada na dinâmica da inventividade da história, que transfere o espaço da morada física e simbólica para um sino, o entáo espaço acolhedor e protetor, mas também de perceber-se sozinha, apesar de acolhida pelas estruturas metálicas e melodiosas, até o gesto da adoção que vem representar a substituição da casa, o encerramento de ciclos, o início de outros, a travessia permanente de percursos, enfim, uma narrativa repleta de 
ofertas para a leitura, entre elas lugares de moradas especiais para a menina surda e para quem se aproximar da história. E, por fim, saindo do universo da literatura infantil e juvenil, fecharíamos o estudo com uma mirada para o livro de crônicas de Mariana Ianelli, Dia de amar a casa, em especial para a crônica que deu título à coletânea, procurando perceber como a autora atribui significado ao espaço de morada nela e em várias outras crônicas da obra na qual o espaço da habitaçáo, casa ou moradia aparece ${ }^{8}$.

Exagero prever tudo isso? Talvez, mas cada um escolhe as verdades nas quais quer acreditar. Nós percebemos com entusiasmo, impulso primário frente a uma chamada da nossa área e só descrevemos o "[...] que poderia ter sido e não foi” (BANDEIRA, 1998, p. 12), justamente para exemplificar algo muito genuíno despertado em nós, principalmente por essa indagação da chamada "Que potências esses modos de ler possuem na continuidade das vidas das obras?”. Quem sabe o exercício de meta-reflexão, meta-pesquisa ou até o jogo de encenação que pode resultar inconscientemente de nossas reflexóes e de nossa pesquisa, que se apresentou aqui já tenha respondido à pergunta. Só basta acrescentar que retomar textos literários, teóricos, outros construídos na convergência dessas duas categorias, como é o caso da tese de Ana e das crônicas de Mariana, conhecer outros, lidos para o projeto original, como é o caso da narrativa juvenil de Celso, foi também uma maneira de encontrar morada subjetiva nesses dias (meses, quase um ano) de morada física forçada que a pandemia da COVID-19 nos condicionou.

\section{Referências}

BACHELARD, Gaston. A poética do espaço. São Paulo: Martins Fontes, 1993.

BANDEIRA, Manuel. Libertinagem - Estrela da manhã (ediçáo crítica). Giulia Lanciani (Coord.). Madrid, París, México. Buenos Aires, São Paulo, Lima, Guatemala, San José, Santiago do Chile: ALLACA XX, 1998.

BENJAMIN. Walter. O narrador: consideraçôes sobre a obra de Nikolai Leskov. In: BENJAMIN. Walter. Magia e técnica, arte e política: ensaios sobre literatura e história da cultura. Tradução de Sergio Paulo Rouanet. São Paulo: Brasiliense, 1985, p. 197-221.

${ }^{8}$ É fundamental registrar que as obras listadas no fechamento, de Lobato à Ianelli, foram apresentadas a partir do recorte que pretendíamos observá-las, e que faremos em outras oportunidades. Elas podem ser observadas por "muitos outros" vieses, possibilidades que lhes garantem o status de literatura que possuem. 
BENJAMIN, Walter. Rua de mão única. In: BENJAMIN, Walter. Obras escolhidas - volume 2. Tradução de Rodrigues Torres Filho e José Carlos Martins Barbosa. São Paulo: Brasiliense, 1985, p. 9-70.

BENJAMIN, Walter. Livros infantis velhos e esquecidos. In: BENJAMIN, Walter. Reflexóes sobre a criança, o brinquedo e a educação. Tradução Marcus Vinicius Mazzari. São Paulo: Duas Cidades, Editora 34, 2002, p. 53-68.

BENJAMIN, Walter. Rua de mão única - extratos. In: BENJAMIN, Walter. Reflexóes sobre a criança, o brinquedo e a educaçáo. Tradução Marcus Vinicius Mazzari. São Paulo: Duas Cidades, Editora 34, 2002, p. 103-109. BOCHECO, Eloí. A casa de consertos. Ilustrações Walther Moreira Santos. São Paulo: Melhoramentos, 2012.

CÂMARA, Ana Letícia Pires Leal. Para Lygia Bojunga, a mulher que mora nos livros. 2010. $254 \mathrm{f}$. Tese (Doutorado em Letras - Estudos da Literatura) - Pontifícia Universidade Católica do Rio de Janeiro, Departamento de Letras, 2010. Disponível em: http://www2.dbd.pucrio.br/pergamum/ biblioteca $/ \mathrm{php} / \mathrm{mostrateses}$. php? open $=1$ \&arqtese $=06106582010$ Indice. html. Acesso em: 18 dez. 2020.

CHEVALIER, Jean; GHEERBRANT, Alain. Dicionário de símbolos. Tradução de Vera da Costa e Silva, Raul de Sá Barbosa, AngelaMelim e Lúcia Melim. 2. ed. Rio de Janeiro: José Olympio, 1989.

COSTA. Marta Morais. E se o leitor invadir a biblioteca proibida? In: COSTA. Marta Morais. Mapa do mundo: crônicas sobre leitura. Belo Horizonte: Leitura, 2006, p. 158-160.

GUTFREIND, Celso. A menina que morava no sino. Ilustrações de Flávio Fargas. Passo Fundo: Psysalis, 2020.

HUIZINGA, Johan. Homo ludens: o jogo como elemento da cultura. Tradução João Paulo Monteiro. São Paulo: Perspectiva, 2007.

HUNT, Peter. A crítica e o livro-ilustrado.In: HUNT, Peter.Crítica, teoria e literatura infantil. Tradução Cid Knipel. São Paulo: Cosac Naify, 2010. p 233-254.

IANELLI, Mariana. Dia de amar a casa. In: IANELLI, Mariana. Dia de amar a casa: crônicas. Porto Alegre: Ardotempo, 2020. p. 121-122.

LIMA, Renata Vilanova. Ilustraçóes em traços e manchas no Design no livro-ilustrado infantil brasileiro contemporâneo. Rio de Janeiro,2012. 263 f. Tese (Doutorado em Design) - Programa de Pós-graduação em De- 
sign, Pontifícia Universidade Católica do Rio de Janeiro, Rio de Janeiro, 2012.

LISPECTOR, Clarice. Felicidade Clandestina. In: LISPECTOR, Clarice. Felicidade clandestina. Rio de Janeiro: Rocco, 1998. p. 9-12.

LOBATO, Monteiro. A barca de Gleyre. São Paulo: Biblioteca Azul, 2010. MANGUEL. Alberto. Uma história da leitura. Tradução Pedro Maia Soares. 2 ed. São Paulo: Companhia das Letras, 2010.

NAKANO, Renata Gabriel. Livro ilustrado: definiçôes, leitores e autores. Rio de Janeiro, 2012, 126 f. Dissertaçáo (Mestrado em Letras) - Programa de Pós-Graduação em Letras, Pontifícia Universidade Católica do Rio de Janeiro, Rio de Janeiro, 2012.

NIKOLAJEVA, Maria; SCOTT, Carole. Livro ilustrado: palavras e imagens. Tradução Cid Knipel. São Paulo. Cosac Naify, 2011.

OBERG, Silvia. (Org.). Um livro pra gente morar. Ilustraçôes de Daniel Cabral. Curitiba: Positivo, 2018.

PETIT, Michèle. A arte de ler ou como resistir à adversidade. Tradução Arthur Bueno e Camila Bordini. São Paulo: Editora 34, 2009.

\section{Dedicatória}

Para os refugiados e imigrantes deste mundo, desejando a segurança que pode estar num livro;

Para o Jobim, nosso cão cantor, que fez a passagem na manhã de Natal deste 2020, para quem, junto com Tom oferecemos casa e ele retribuiu com muito afeto e música, até que duvidem que um cáo cante e estraguem a sinceridade da dedicatória. Terminar essa escrita foi uma maneira de te homenagear, querido, e seguir, agora, sem o teu canto;

Para todos os que continuam, apesar da violência que sofreram e sofrem em muitos espaços acadêmicos: continuem escrevendo, inclusive em primeira pessoa; quando for necessário, usem-na no plural, assim, de alguma maneira, nos daremos as máos, ou as vozes, e cantaremos, como fazia o Jobim. 